Журнал «Герспективитаінноваціїнауки

(Серія «Педагогіка», Серія «Гиихологія», Серія«Медицина»

№5(5) 2021

УДК 159.9:159.972

https://doi.org/10.52058/2786-4952-2021-5(5)-814-826

Синишина Вікторія Михайлівна доктор педагогічних наук, доцент, доцент кафедри психології, Державний вищий навчальний заклад «Ужгородський національний університет», пл. Народна, 3, м. Ужгород, тел.: (095) 540-06-13, e-mail: vsinishina@ukr.net, https:// orcid.org/0000-0002-7993-1638

\title{
РЕАБІЛІТАЦІЯ ВІЙСЬКОВОСЛУЖБОВЦІВ ЗАСОБАМИ ДЕБРИФІНГУ
}

Анотація. У статті зроблена спроба з'ясувати можливості використання дебрифінгу як реабілітаційного заходу для військовослужбовців. Вказано, що психологічна реабілітація це комплекс психологічних заходів, які спрямовані на стабілізацію не тільки функціонального стану організму, а й емоційної, мотиваційної, вольової, когнітивної сфер особистості та відновлення професійно й особистісно важливих якостей, від яких залежить ефективність діяльності. Визначено за підсумковим аналізом результатів, які отримано за методикою FPI, що для військових експериментальної групи, які проходили реабілітаційні заходи із застосуванням дебрифінгу, притаманні високі рівні урівноваженості, відкритості, екстраверсії, маскулінізму та низькі рівні невротичності, спонтанної агресивності, депресивності, стресочутливості, подразливості, високі рівні стресостійкості, урівноваженості, відкритості та емоційної лабільності, що зумовило емоційну стабільність, стійкість до стресу, упевненість у собі, оптимізм, активність, прагнення до співпраці, соціальних контактів, довірливо-відвертого спілкування, самокритичності та достатньо вираженої саморегуляції. Для військових доекспериментальної групи визначено високий рівень урівноваженості, відкритості, екстраверсії, середній рівень невротичності, спонтанної агресивності, подразливості, комунікабельності, стресочутливості, емоційної лабільності та низький рівень депресивності.

Водночас, у військових контрольної групи за методикою FPI з ясовано, що представники цієї групи мають високий рівень невротичності, спонтанної агресивності, подразливості, реактивної агресивності, стресочутливості, емоційної лабільності та низький рівень комунікабельності, урівноваженості і середньо виражену депресивність.

Ключові слова: військовослужбовці, дебрифінг, реабілітація, Фрайбурзький особистісний опитувальник, стрес-чинники, емоційна стійкість.

Synyshyna Viktoriia Mykhailivna Doctor of Pedagogical Sciences, Associate Professor, Associate Professor of the Department of Psychology of the State institution of higher education «Uzhhorod National University», Narodna Square, 3, Uzhhorod, tel.: (095) 540-06-13, e-mail: vsinishina@ukr.net, https:// orcid.org/00000002-7993-1638 


\section{REHABILITATION OF COMBATANTS DEBRIFING MEANS}

Abstract. The article attempts to clarify the possibility of using debriefing as a rehabilitation measure for servicemen. It is stated that psychological rehabilitation is a set of psychological measures aimed at stabilizing not only the functional state of the body, but also emotional, motivational, volitional, cognitive spheres of personality and restoration of professionally and personally important qualities on which efficiency depends. Determined by the final analysis of the results obtained by FPI, that the military experimental group, which underwent rehabilitation measures using debriefing, are characterized by high levels of balance, openness, extraversion, masculinity and low levels of neuroticism, spontaneous aggression, irritability, depression high levels of stress resilience, balance, openness and emotional lability, which led to emotional stability, resilience to stress, self-confidence, optimism, activity, desire for cooperation, social contacts, trusting communication, selfcriticism and sufficient self-regulation. For the military of the pre-experimental group, a high level of balance, openness, extraversion, a medium level of neuroticism, spontaneous aggression, irritability, sociability, stress sensitivity, emotional lability and a low level of depression were determined. At the same time, the military control group according to the FPI method found that members of this group have a high level of neuroticism, spontaneous aggression, irritability, reactive aggression, sensitivity, emotional lability and low levels of sociability, balance and moderate depression.

Keywords: servicemen, debriefing, rehabilitation, Freiburg personality questionnaire, stressors, emotional stability.

Постановка проблеми. Актуальність проблеми дослідження негативного впливу стресу на психіку військовослужбовців $є$ однією з провідних в рамках психології діяльності в особливих умовах, екстремальної та кризової психології. Аналіз діяльності військових вказує на те, що вони повсякчас наражаються на вплив негативних чинників професійного стресу. У більшості випадків стрес-чинники спричинюють ускладнення у діяльності через пролонговані психічні перевантаження, що зумовлюються виникненням непередбачених надзвичайних ситуацій, високим рівнем відповідальності за виконання поставлених завдань, реальними загрозами для власного життя та здоров'я тощо. Через це важливою та нагальною проблемою є відновлення позитивного емоційного фону військовослужбовців задля майбутнього психологічного та професійного благополуччя. К. К Платонов і В.Л. Марищук у книзі «Військова інженерна психологія» запропонували поняття емоційної стійкості розуміти як здатність управляти своїми емоціями, зберігати високу професійну працездатність, здійснювати складну або небезпечну діяльність без надмірного напруження, незважаючи на емоціогенні впливи. Відтак, коли військові після бойових подій, вже переживають негативні психічні стани, що детерміновані стрес-чинниками, необхідно впроваджувати реабілітаційні 
заходи з метою відновлення їх психічного здоров'я [1].

При визначенні психологічної реабілітації слід керуватися розумінням реабілітації як комплексу психологічних заходів, які спрямовані на стабілізацію не тільки функціонального стану організму, а й емоційної, мотиваційної, вольової, когнітивної сфер особистості та відновлення професійно й особистісно важливих якостей комбатантів, від яких залежить ефективність діяльності.

Виходячи 3 такого визначення необхідно виокремити діагностичний, лікувально-відновлюваний та професійно-відновлюваний етапи психологічної реабілітації:

В лікувально-відновлювальному етапі слід виділити три основних напрямки реабілітації: психофізіологічий, психокорекційний, соціальнопсихологічний.

Психофізіологічний напрямок полягає в діагностиці та відновленні професійно важливих якостей комбатантів, при цьому використовуються психодіагностичні комп'ютерні методики. В психокорекційній та соціальнопсихологічній роботі доцільно використовувати психологічне консультування, психотерапію, сугестотерапію, ауторелаксаційні техніки; психологічний дебрифінг, соціально-психологічний тренінг, метод біологічного зворотнього зв'язку та інші.

Одним 3 найбільш ефективних методів психологічної реабілітації є так званий психологічний дебрифінг. Він являє собою організоване в процесі групової роботи обговорення травмуючих та стресогенних подій, які сумісно переживались группою військовослужбовців при виконанні спільного бойового завдання.

Аналіз останніх досліджень i публікацій. Питання психологічної стійкості фахівця до виконання завдань в складних та екстремальних умовах професійної діяльності має досить пророблені теоретичні основи і практичні результати завдяки дослідженням М. Корольчука, Г. Ложкіна, С. Максименка, В.Моляко, Ю. Олександровського, С. Потапчука, О. Сафіна, Н. Тарабриної, О. Тімченка, М.Томчука, С.Яковенка та інших авторів, iї не можна вважати повністю вирішеною.

В останні роки дослідженню негативного впливу стресу на психіку фахівця були присвячені праці українських вчених В. Корольчук, К. Кім, А.Кулаженко, В. Лефтерова, С. Лебедєвої, С. Миронця, В. Осьодла, В. Садкового, О. Сафіна, Л. Перелигіної, А. Побідаша, М. Хвороста, C. Яковенка та ін. Психологічні чинники впливу бойових дій на стан військовослужбовців проаналізовані у дослідженнях українських науковців О. Бойка, А. Бородія, В. Крайнюк, Є. Литвиновського, О. Макаревича, А. Романишина та ін. Загальні підходи до організації процесу реабілітації визначені у працях I. Мисули, М. Фролова, С. Харченка, Л. Яковлевої та ін. Серед вітчизняних науковців, що вивчають реабілітацію військовослужбовців, В. Алещенко, Н. Олексюк, Н. Пономаренко, О. Савченко, В. Турбан, О. Хміляр 
та ін.). Зарубіжні дослідники L. Calhoun, R. Laufer, R. Skurfield, C. Williams та ін. вивчали методи та техніки психологічної реабілітації. У дослідженнях згаданих авторів ставилось за мету виявити стрес-фактори або їх посттравматичні наслідки, що мали вплив на психіку фахівця в динаміці професійної діяльності, а також обгрунтувати засоби для відновлення психологічного здоров'я, та, зокрема, психологічної стійкості методами реабілітації. Водночас, проблема реабілітації фахівців екстремального профілю до професійного стресу відзначається своєю складністю, неузгодженістю і недостатністю розробленості прикладних засад їі формування.

Мета статті - полягає в обгрунтуванні доцільності застосування дебрифінгу через визначення динаміки показників шкал Фрайбурзького особистісного опитувальника.

Для реалізації мети було проведено дослідження за діагностичною методикою «Фрайбурзький особистісний опитувальник», яка застосовувалась до та після проведення з військовослужбовцями методу дебрифінгу.

Дослідження проводилось на базі однієї 3 військових частин, респондентами виступили комбатанти у кількості 46 чоловік, які виконували свій військовий обов'язок у зоні АТО; вік досліджуваних - від 25 до 53 років, бойовий досвід від 6 місяців - до 2,4 років. Експериментальну групу склали комбатанти у кількості 23 осіб та контрольну групу у кількості 23 осіб. Доексперементальна група була обрана в такій же кількості.

Виклад основного матеріалу. Одним із способів вирішення проблеми негативного впливу стресу на психіку військовослужбовців є використання групових форм психокорекційного впливу. Зазвичай в гострій фазі постстресових порушень групові форми не використовуються, однак на етапах завершення катастрофічної ситуації їх застосування $\epsilon$ адекватним та ефективним. Групові психокорекційні техніки показані в тих випадках, коли люди пережили спільну (колективну) травму. До таких відноситься перш за все метод «дебрифінгу», розроблений американським психологом Д. Мітчелом в 1983 році, в якому в найбільш структурованому вигляді представлений процес роботи 3 наслідками колективної психічної травми [2]. Психологічні дебрифінги як форма надання реабілітаційної допомоги в кризових ситуаціях проводяться з групами людей, що об’єднані загальною пережитою ситуацією. Мета дебрифінгу - мінімізувати негативні психологічні наслідки та попередити розвиток ПТСР у постраждалих.

Процес дебрифінгу зазвичай складається з таких основних фаз: 1) фаза відтворення ходу події; 2) фаза обговорення емоційного стану учасників під час події; 3) фаза виявлення симптомів стресу; 4) фаза навчання (інформування про природу стресових реакцій, про навички їх самодіагностики); 5) фаза закінчення дебрифінгу (пояснюється, в яких випадках слід звертатися за професійною медико-психологічною допомогою) [2].

Також науковці виділяють у дебрифінгу три частини й сім чітко виражених фаз: 
Журнал«Герспективитаінновації наукиљ

(Серія«Гедагогіка», Серія«Гtиххологія», Серія«Медицинф»

№5(5) 2021

частина I - пропрацювання основних почуттів учасників i вимір інтенсивності стресу;

частина II - детальне обговорення симптомів і забезпечення почуття захищеності й підтримки;

частина III - мобілізація ресурсів, забезпечення інформацією й формування планів на майбутнє.

Нижче сформульовані й описані сім фаз дебрифінгу.

\section{1. Вступна фаза}

Вступна фаза дуже важлива: якщо вона проведена на професійному рівні, організовано, це зменшує ймовірність того, що група буде погано функціонувати надалі. Чим більше часу витрачено на введення, тим менше шансів, що що-небудь піде неправильно. Типовий час, який витрачається на введення, - 15 хв.

Ведучий групи представляє себе, команду дебрифінгу й пояснює мету зустрічі приблизно в такий спосіб: «Я - N... Таку процедуру обговорення того, що трапилося, я використовував багато разів раніше в подібних ситуаціях після складних, стресогенних інцидентів, таких, як... Ці обговорення більшість людей визнають корисними. Вони дають можливість висловити й зрозуміти думки й почуття, які виникли в нас у зв'язку з тим, що відбулося. Тому все, що буде тут обговорюватися, ми будемо вважати нормальним. Це допоможе вам розібратися у своєму стані й почуттях, які зараз здаються вам дивними й неподоланними».

Ведучий ознайомлює 3 основними завданнями дебрифінгу. Учасники можуть висловлювати побоювання, що вони не зуміють що-небудь повідомити за фактом або не зможуть сформулювати свою проблему.

Ведучий роз'яснює, що дебрифінг - це нове для них заняття, у якому вони ніколи не брали участь. Тому те, наскільки добре вони будуть це робити, 3'ясується в процесі обговорення. Такий підхід задає певну систему очікувань: всім присутнім потрібно говорити про свої думки і почуття й відчути це заняття корисним.

Потім ведучий визначає правила для дебрифінгу. Правила потрібні, щоб мінімізувати тривогу, яка може бути в учасників.

1. Звичайно, члени групи заспокоюються, почувши про те, що жодного 3 них не будуть змушувати говорити що-небудь взагалі, якщо він не побажає цього робити. Єдина вимога полягає в тому, що вони повинні назвати своє ім'я й висловити ставлення до катастрофи або до тієї події, учасником або свідком якої вони були. Однак членів групи просять намагатися вислуховувати всіх, не перебиваючи.

2. Члени групи повинні бути впевнені в дотриманні конфіденційності змісту зустрічі. Аналогічно членів групи просять не передавати кому-небудь за межами цього кола особистої інформації про інших учасників, «не брехати» про те, що вони можуть сказати прямо одне одному. Необхідно зняти страх, заспокоїти учасників щодо того, що відповіді не будуть записувати мимо їхньої 
волі. Однак, з іншого боку, їм можна повідомити, що було б корисним для команди дебрифінгу зробити запис фактів і думок без вказівки авторства. Якщо потім це швидко передрукувати, то згодом люди зможуть ще раз звернутися до матеріалу, що обговорювався в групі для зняття ілюзій, які виникають 3 приводу того, що відбувалося.

3. Потрібно, щоб члени групи знали, що дебрифінг не допускає оцінок, критики й вироків. Це не трибунал, а лише процедурне обговорення. Подібна установка попереджає суперечки, взаємні обвинувачення, які можуть виникнути через розбіжність в очікуваннях, думках і почуттях.

Однак ведучі психологічного дебрифінгу можуть дозволити відкрито висловлюватися із приводу процесу обговорення, критикувати, інакше люди будуть займатися цим після дебрифінгу.

4. Учасників попереджають, що під час самого обговорення вони можуть відчути себе гірше, але це - нормальне явище, звичайний наслідок дотику до хворобливих проблем. Ведучий повинен зазначити, що це частина плати за можливість згодом протистояти стресам.

5. Членам групи рекомендують працювати без перерви. Тому їм можна запропонувати перекусити або відвідати туалет до початку дебрифінгу. До речі, корисно мати кавоварку або чайник, щоб кожний міг обслужити себе під час дебрифінгу.

6. Учасникам повідомляють, що в них $\epsilon$ можливість тихо вийти й повернутися назад. Однак їх просять повідомляти ведучому, якщо вони йдуть у негативному стані, і тоді членам команди, одному або декільком, потрібно супроводжувати їх.

7. Членам групи надається можливість обговорювати дещо, що виходить за рамки заданої теми, і ставити будь-які питання. Важливо пам'ятати, що в учасників може бути мінімальний досвід обговорення, проявів свого «Я» у груповому контексті. В інших такого досвіду може й зовсім не бути. На команді дебрифінгу лежить відповідальність за заохочення й заспокоєння членів групи, особливо на початку дебрифінгу.

\section{2. Фаза фактів}

На цій фазі кожна людина коротко описує, що відбулося з нею під час інциденту. Учасники можуть описати, як вони побачили подію і яка була послідовність етапів. Ведучий команди дебрифінгу повинен заохочувати фактологічні перехресні питання, що допомагають прояснити й відкоригувати об'єктивну картину фактів і подій, наявних у розпорядженні членів групи. Це важливо, оскільки через масштаб інциденту й помилок сприйняття кожна людина реконструює картину по-своєму. Це можуть бути просто неправильні переживання подій або ж наявність помилкових ключових уявлень про них. Відчуття часу також часто буває порушено.

Знання фактів й їхньої послідовності допомагає впорядкувати те, що трапилося, створити структуру події. Це одне з головних завдань дебрифінгу дати людям можливість більш об’єктивно побачити ситуацію, що блокує 
Журнал«Герспективитаінновації наукиљ

(Серія«Гедагогіка»), Серія«ГТихологія», Серія «Медицина»

№5(5) 2021

фантазії й спекуляції, які підігрівають тривогу.

\section{3. Фаза думок}

На фазі думок дебрифінг фокусується на процесах ухвалення рішення й мислення. Питання, що відкривають цю фазу, можуть бути такого типу: «Якими були ваші перші думки, коли це відбулося? Коли ви повернулися на місце дії? і т.п.»

Люди часто проявляють опір, коли діляться своїми першими думками, тому що ці думки їм здаються недоречними, вигадливими, вони відбивають інтенсивне почуття страху. Перша думка може відображати те, що згодом становить серцевину тривоги.

Потім варто запитати: «Що ви робили під час інциденту? Чому ви вирішили робити саме те, що ви робили?» Це останне питання часто відображає прагнення захистити тих, в кого з'являються перші тривожні думки.

\section{4. Фаза реагування}

Питання про думки, враження й дії сприяють емоційному відреагуванню. Ця фаза, у якій досліджуються почуття, часто найдовша частина дебрифінгу. Для того, щоб досягти успіху в цій фазі, ведучому потрібно допомагати людям розповідати про свої переживання, навіть хворобливі. Це може зменшити руйнівні наслідки таких почуттів.

Коли люди описують причини прийняття ними тих або інших рішень, вони дуже часто говорять про страх, безпорадність, самотність, фрустрації. Типові наступні коментарі: «Я так боявся зробити помилки...»; «Я знав, що якщо я не зможу...»; «Я ніколи у своєму житті не був так переляканий».

Груповий принцип універсальності $є$ тут ключовим. Цьому сприяють питання, наприклад:

«Як ви реагували на подію?..»; «Що для вас було найжахливішим 3 того, що трапилося?..»; «Чи переживали ви у вашому житті раніше що-небудь подібне?..»; «Як ви себе почували, коли відбулася подія?..».

Якщо в когось із учасників погіршується стан, то це ключовий момент для мобілізації групової підтримки, сигнал сусідові: покласти руку на плече людини, що перебуває в стані дистресу, або просто вербалізувати підтримку, сказавши, що сльози тут цілком доречні й прийнятні.

\section{5. Фаза симптомів}

Під час фази симптомів деякі реакції повинні бути обговорені детальніше. Учасників просять описувати симптоми (емоційні, когнітивні, фізичні), які вони пережили на місці події, коли інцидент завершився, коли вони повернулися додому, протягом наступних днів й на цей час. Питання про незвичайні переживання, про труднощі повернення й відновлення нормального режиму життя й роботи - обов'язкові.

До характерних рис посттравматичного стресу належать переживання феномену уникнення, заціпеніння. Страх може викликати зміни в поведінці. Фобічні реакції (страхи) можуть проявлятися в тому, що люди не можуть 
повернутися на те місце, де відбулася подія (особливо проблемним стає, якщо це місце їхньої основної роботи).

\section{6. Завершальна фаза}

У цій фазі один з ведучих повинен узагальнити реакції учасників.

Цей акцент на аналізі реакцій демонструє тим, хто зібрався, що їхня реакція цілком нормальна, що це «нормальна реакція на ненормальні події». Але індивідуальність кожного також повинна бути врахована. В учасників не повинно скластися враження, що вони зобов'язані виражати емоції, але вони повинні знати, що вони завжди зможуть зробити це, якщо захочуть. Важливо відзначити такі реакції, як почуття тривоги, почуття вразливості, проблеми зі сном і з концентрацією уваги. Необхідно відзначити, що нічого страшного в цих реакціях немає, й при нормальному розвитку подій згодом симптоми будуть зменшуватися.

\section{7. Фаза реадаптації}

У цій фазі обговорюється й планується майбутнє. Однією з головних цілей дебрифінгу, крім усього іншого, є створення внутрішньогрупового психологічного контексту. Переживання, викликані відсутністю розуміння 3 боку навколишніх, можливо, один із найтравматичніших аспектів посттравматичного стресу. Напрямок подальшої допомоги доцільно уточнити. Група може ухвалити рішення щодо необхідності наступного дебрифінгу або, як мінімум, визначити можливість його проведення, якщо інцидент був особливо травматичним або не вдалося впоратися із проблемами.

Дебрифінг може мати продовження через кілька тижнів або навіть місяців. Цей процес уже менш структурований в порівнянні 3 першим, і його головне завдання - простежити прогрес учасників у межах симптомів, щоб упоратися 3 ними.

До того як застосувати дебрифінг та після його застосування ми провели дослідження за «Фрайбурзьким особистісним опитувальником», в результаті чого визначені наступні дані.

Аналіз отриманих результатів за Фрайбурзьким особистісним опитувальником (табл. 1) показав, що за першою шкалою - невротичності у представників ДЕГ - (доекспериментальної групи) цей показник на 1,1 6. виявився нижчим, відносно показників КГ i на 0,5 б вищим, ніж у обстежуваних ЕГ (при $\mathrm{p}<0,05)$. Порівняння результатів за шкалою невротичності показує, що вони виявилися достовірно нижчі у військових ЕГ, після застосування дебрифінгу у порівнянні з контрольною групою.

Отже, за даними цієї методики показник невротизації - у військових, 3 якими проводилися заняття в рамках де брифінгу знаходиться на рівні 2,5 $\pm 0,05$ б, що свідчить про низький рівень ㄲi вираженості у даної категорії обстежуваних. У ДЕГ цей показник зафіксовано на рівні 3,0土0,01 б, що відповідає нижчому рівню середньої вираженості невротичності. Найбільш вираженим показник невротичності виявився у військових КГ- на рівні 4,1士0,04 б, тобто, більш наближеним до високого діапазону, що свідчить про 
Журнал«Герспективитаінновації наукиљ

(Серія «Гедагогіка», Серія«ГТихологія», Серія«Медицина»

№5(5) 2021

більший прояв невротичності у представників цієї групи.

Отже, за підсумками аналізу проявів невротичності методики FPI з ясовано, що низький рівень притаманний представникам ЕГ та ДЕГ, більш високий рівень невротичності спостерігався у КГ.

Табличя 1.

Результати Методики FPI

\begin{tabular}{|c|c|c|c|c|}
\hline \multirow{3}{*}{ Шкали } & \multicolumn{4}{|c|}{ Групи } \\
\hline & \multicolumn{2}{|c|}{ До експерименту } & \multicolumn{2}{|c|}{$\begin{array}{c}\text { Після } \\
\text { експерименту }\end{array}$} \\
\hline & КГ & ЕГ & КГ & $\mathrm{E} \Gamma$ \\
\hline 1.Невротичність & $3,0 \pm 0,01$ & $3,0 \pm 0,01$ & $4,1 \pm 0,04$ & $\begin{array}{l}2,65 \pm \\
0,05\end{array}$ \\
\hline 2.Спонтанна агресивність & $5,1 \pm 0,02$ & $5,2 \pm 0,04$ & $5,1 \pm 0,02$ & $3,2 \pm 0,01$ \\
\hline 3.Депресивність & $3,0 \pm 0,02$ & $3,1 \pm 0,02$ & $3,0 \pm 0,04$ & $2,8 \pm 0,07$ \\
\hline 4.Подразливість & $5,0 \pm 0,05$ & $5,0 \pm 0,07$ & $5,3 \pm 0,08$ & $3,6 \pm 0,04$ \\
\hline 5.Комунікабел & $5,2 \pm 0,03$ & $5,3 \pm 0,05$ & $5,4 \pm 0,01$ & $6,0 \pm 0,03$ \\
\hline 6.Урівн & $5.0 \pm 0,04$ & $5,0 \pm 0,07$ & $5,2 \pm 0,03$ & $7,5 \pm 0,05$ \\
\hline 7.Реактивна агресивність & $6,1 \pm 0,03$ & $6,2 \pm 0,05$ & $6,6 \pm 0,05$ & $6,0 \pm 0,04$ \\
\hline 8. Сором'язливість & $5,0 \pm 0,01$ & $5,1 \pm 0,02$ & $5,0 \pm 0,03$ & $3,2 \pm 0,03$ \\
\hline 9. Відкритість & $6,0 \pm 0,02$ & $6,2 \pm 0,04$ & $6,0 \pm 0,09$ & $6,0 \pm 0,01$ \\
\hline 10. Екстра-інтроверсія & $5,4 \pm 0,03$ & $5,6 \pm 0,06$ & $5,8 \pm 0,04$ & $6,6 \pm 0,06$ \\
\hline 11. Емоційна лабі. & $3,1 \pm 0,05$ & $3,2 \pm 0,04$ & $4,0 \pm 0,03$ & $2,7 \pm 0,01$ \\
\hline 12. Маскулінізм-фемінізм & $7,0 \pm 0,06$ & $7,2 \pm 0,07$ & $7,0 \pm 0,03$ & $7,2 \pm 0,07$ \\
\hline
\end{tabular}

Примітка: рівні достовірності (при р <0,05).

Високий рівень показників за шкалою невротичності у військових КГ свідчить про наявність у них вираженого невротичного синдрому з можливими психосоматичними порушеннями.

Рівень спонтанної агресивності у ДЕГ був на 2 б. вищим порівняно з ЕГ, відповідно $(5,2 \pm 0,04)$ проти $3,2 \pm 0,01)$ та на 0,1 б. нижчим порівняно 3 рятувальниками КГ $(5,1 \pm 0,02)$.

Аналіз отриманих показників свідчить, що найменш виражена спонтанна агресивність була виявлена у обстежуваних ЕГ та ДЕГ, це вказує на те, що показники досліджуваних груп знаходяться в межах середнього рівня вираженості (3-6 б.). Водночас, зазначимо, що особи КГ знаходяться на нижньому рівні середніх оцінок, а представники ЕГ все ж таки мають, хоча i середні показники, але у порівнянні з КГ вони мають певні відмінності в кращий бік $(\mathrm{p}<0,05)$, що свідчить про можливі погіршення або поліпшення цих показників у залежності від внутрішніх чи зовнішніх чинників та рівня психологічного забезпечення професійної діяльності цієї категорії обстежуваних. 
Отже, порівняльний аналіз показників за шкалою спонтанної агресії методики FPI свідчить про те, що у військових ЕГ цей показник знаходиться на межі низької і середньої оцінки, у КГ та ДЕГ - спонтанна агресивність виражена у межах середніх величин, що вказує на те, що є недостатній рівень сформованості регуляторних компонентів стресостійкості У таких осіб, як правило, просліджується підвищений рівень психопатизації, а відповідно $є$ більш вірогідні передумови щодо імпульсивної поведінки в умовах виникнення екстремальних ситуацій.

Третя шкала - депресивність дає змогу діагностувати ознаки, характерні для осіб 3 депресивним синдромом. Високі оцінки за цією шкалою відповідають наявності певних ознак в емоційному стані, в поведінці, у ставленні до себе і соціального середовища.

Аналіз результатів за шкалою депресії показує, що в усіх трьох груп досліджуваних, цей показник був у межах норми і становив: ДЕГ - 3,1土0,02б.;

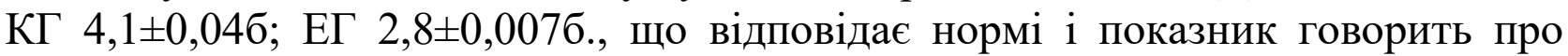
відсутність депресивності. Водночас у ЕГ цей показник був нижчим, порівняно з до експериментальною та контрольною групами.

Четверта шкала методики FPI "подразливість" - дає змогу оцінити рівень емоційної стійкості. Високі оцінки свідчать про негативний емоційний стан зі схильністю до агресивного реагування.

Аналіз результатів обстежуваних за четвертою шкалою методики FPI подразливість, свідчить про те, що в ЕГ цей показник на 1,6 (p<0,05) нижчий, ніж у КГ. Показники ДЕГ практично співпадали $з$ показниками КГ і становили $5,0 \pm 0,076$.

Таким чином, за інтерпретацією отриманих результатів можемо стверджувати, що для осіб ЕГ притаманний високий рівень емоційної стійкості, для осіб ДЕГ та КГ - середній рівень емоційної стійкості. При цьому рівень схильності до афективного реагування у цих груп був відповідно вищим, і наближався до граничного.

П'ята шкала методики FPI - комунікабельність характеризує, як потенційні можливості, так i реальні прояви соціальної активності обстежуваних.

Аналіз отриманих результатів за шкалою комунікабельності FPI показав,

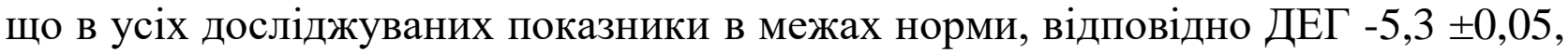

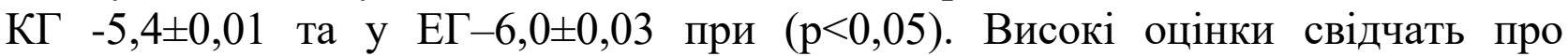
наявність вираженої потреби у спілкуванні.

Шоста шкала - урівноваженість за методикою FPI, відображає рівень стійкості до стресу. Високі оцінки свідчать про хорошу захищеність до дії стрес-факторів, стійкості до дії звичайних життєвих ситуацій, що базуються на упевненості у собі, оптимістичності та активності.

Аналіз результатів, отриманих за шкалою урівноваженості показав, що іiі рівень на 2,2 бали виражений більше у військових ЕГ у порівнянні до КГ $(\mathrm{p}<0,05)$. Та на 1,5 б. вищі у порівнянні з ДЕГ групою $(\mathrm{p}<0,05)$. 
Отже, особливістю отриманих результатів за шкалою урівноваженості в КГ та ЕГ досліджуваних, виявилось те, що ці показники в обох групах знаходяться на високому рівні. Це свідчить про те, що представники обох груп володіють високим рівнем захищеності від дії стрес-чинників екстремальних ситуацій, що базуються на впевненості у собі, оптимістичності й активності.

Водночас, цей показник, хоч і незначно, все ж таки був вищий на 0,5 б. у військових ЕГ після застосування дебрифінгу.

Сьома шкала за методикою FPI - реактивна агресивність.

Високі оцінки свідчать про агресивне ставлення до соціального оточення $\mathrm{i}$ вираженим прагненням до домінування. Якщо прагнення до домінування - це відображення специфіки діяльності, то досить високий рівень агресивного ставлення до соціального оточення учасників опитування (у 90\% випадків) зумовлено низьким рівнем соціальної захищеності i низьким рівнем соціального визнання як матеріального так і морального характеру в умовах суворої дисципліни, високої відповідальності та наявності впливу особливих (екстремальних) чинників діяльності.

За результатами обстеження трьох груп показник реактивної агресивності виражений на рівні 6,0 балів і вище. Так, зокрема: у ДЕГ, цей показник був вираженим на рівні $6,2 \pm 0,05$ б. - у військових КГ - 6,6 $\pm 0,05$ б. і на рівні $6,0 \pm 0,04$ б - у військових ЕГ, що свідчить про дещо завищені прояви реактивної агресивності у всіх досліджуваних груп.

За восьмою шкалою методики FPI - сором'язливість високі оцінки свідчать про наявність тривожності, скутості, невпевненості, наслідком чого $€$ труднощі в соціальних контактах.

Аналіз отриманих результатів за шкалою сором'язливість методики FPI свідчить, що у ЕГ цей показник на 1,6 б нижчий, ніж у КГ і на 1,8 б. нижчий, ніж у обстежуваних ДЕГ $(\mathrm{p}<0,05)$.

У цілому, показники обох груп свідчать про упевненість у собі, схильність до контактів у соціальному середовищі.

Водночас, значно вищий рівень за шкалою сором'язливості методики FPI спостерігаємо у КГ, це вказує на схильність представників цієї групи до стресового реагування на звичайні життєві події, що здійснюється за пасивнозахисним типом та наявність тривожності, скутості, невпевненості, труднощів у соціальних контактах.

За дев'ятою шкалою методики FPI - відкритістю, характеризують ставлення до соціального оточення і рівень самокритичності. Високі оцінки свідчать про прагнення до довірливо-відвертої взаємодії з оточуючими людьми i про високий рівень самокритичності. Оцінки за цією шкалою можуть тією чи іншою мірою сприяти аналізу щирості відповідей обстежуваних при роботі 3 даними досліджуваних, що відображається шкалою відвертості, відповідності інших опитувальників.

За аналізом показників дев ятої шкали - відкритості за методикою FPI з'ясовано, що показник відкритості у всіх досліджуваних груп знаходилися 
практично на одному рівні і становили показники в межах 6,0-6,3б.

Отже, у цілому, треба зазначити, що показник відвертості у всіх групах дозволяли нам отримувати статистично достовірні результати.

За десятою шкалою методики FPI визначено рівень екстраверсії інтроверсії. Високі оцінки за цією шкалою відповідають вираженій екстравертованості особистості, а низькі - вираженій інтровертованості.

За аналізом результатів обстеження за методикою FPI шкали екстравертованості - інтровертованості 3'ясовано, що у ЕК цей показник виявився на 0,7 б. у порівнянні з КГ і на 1.0 б. у порівнянні з ДЕГ був нижчим $(\mathrm{p}<0,05)$. Отже, отримані результати свідчать про те, що у всіх групах показник екстраверсії-інтраверсії був представлений в межах норми.

Одинадцята шкала методики FPI - емоційна лабільність. Iї високі показники вказують на нестійкість емоційного стану, що виявляється у частих коливань настрою, підвищенні збудженості, дратівливості, недостатній самореалізації.

За результатами аналізу показників емоційної лабільності виходить, що у військових ЕГ він на 1,2 б. нижчий у порівнянні з рятувальниками КГ та на 0,4 б. у ДЕГ $(\mathrm{p}<0,05)$.

За аналізом результатів за шкалою маскулінізм - фемінізм методики FPI, з'ясовано, що для осіб трьох груп притаманно високий рівень показників маскулінізму, які найбільш виражені були рівномірно представлені у всіх

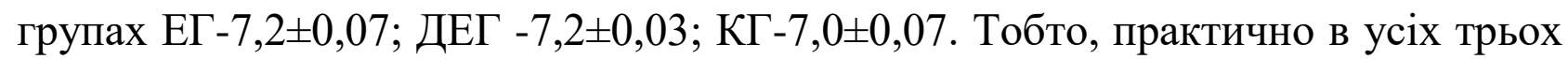
групах перебіг психічної діяльності здійснюється переважно за чоловічим типом.

Висновки. Таким чином, за підсумковим аналізом результатів, які отримано за методикою FPI з ясовано, що для військових ЕГ, які здійснювали реабілітацію із застосуванням дебрифінгу притаманні високі рівні урівноваженості, відкритості, екстраверсії, маскулінізму та низькі рівні невротичності, спонтанної агресивності, депресивності, стресочутливості, подразливості, високі рівні стресостійкості, урівноваженості, відкритості та емоційної лабільності, що зумовило емоційну стабільність, стійкість до стресу, упевненість у собі, оптимізм, активність, прагнення до співпраці, соціальних контактів, довірливо-відвертого спілкування, самокритичності та достатньо вираженої саморегуляції, що свідчить про ефективність психоребілітаційних заходів.

\section{Лimepamypa:}

1. Шестопалова Л.Ф. Дебрифинг как метод психологической коррекции посттравматических стрессовых нарушений: методическое пособие. Харьков: Ун-т внутр. дел, 1998. $18 \mathrm{c.}$

2. Малкина-Пых И. Г. Психологическая помощь в кризисных ситуациях: справоч. практ. психолога. М.: Эксмо, 2010. 960с. 


\section{References:}

1. Shestopalova, L.F. (1998). Debryfynh kak metod psykholohycheskoi korrektsyy posttravmatycheskykh stressovblkh narushenyi: metodycheskoe posobye [Debriefing as a method of psychological correction of post-traumatic stress disorders]. Kharkov: Un-t vnutr. Del. [in Ukrainian].

2. Malkyna-Pыkh, Y. Н. (2005). Psykholohycheskaia pomoshch v kryzysnblkh sytuatsyiakh: spravoch. prakt. psykholoha [Psychological assistance in crisis situations: reference. practical psychologist]. Moscow: Эksmo [in Russian]. 